\title{
The Necessity of Re-reading and Re-writing of African American's History and Life: Through the Analysis of Toni Morrison's Beloved
}

\author{
Mi-A Kim1)
}

\begin{abstract}
Toni Morrison is one of the most influential black female writers in world history. Morrison unceasingly tried to heal African American's traumatic scar and restore African American's uniqueness and blackness existing in the hidden American society. Therefore she insisted necessity of forgotten and un-textured African American's culture and convention, and digging up the hidden truth on black culture in American society. Toni Morrison strongly advocated the importance of keeping black uniqueness, and her constant effort helps African Americans establish intrinsic self-esteem as a complete human being. With this historical consciousness, Morrison has recorded social and cultural vehemence of African Americans in American history in her novels. This paper will look into forgotten and un-textured truth of American society by following the footsteps of Toni Morrison's unceasing effort for it. Methodologically, this study will examine functions of speaking, hearing, recalling and sharing of the past history in American society, and how it is connected to healing of African Americans and reconciliation of American society based on Peter Carafiol's assertion. For suggesting more objective basis of this research, it will analyze psychological change of main characters in Toni Morrison's Beloved.
\end{abstract}

Keywords: Recalling, Sharing, Speaking, Hearing, Reconciliation

\section{Introduction}

Toni Morrison is the African American female writer, who thought the duty as a black female writer is to record a story of African American's uniqueness and their community culture. She insists that the responsibility of African American literature dig up forgotten and un-textured African American's unique culture and black spirit in American society[1]. Morrison constantly claims to restore African American's history buried in the silence of American society. This is linked with Morrison's philosophy as a writer that African Americans must not be indulged in to the illusion of American dream and keep themselves from assimilating into white society. That means black people should reject the norm set by the whites' own standards.

With this historical consciousness, Morrison tries to record the social and cultural vehemence

Received(January 10, 2020), Review Result(1st: February 17, 2020, 2nd: April 02, 2020), Accepted(May 27, 2020)

1) (Associate Professor) 55069 Dept. Superstar college, Jeonju Univ., Hyeojadong, Cheonjamlo 303, Jeonju, Korea

email: kmia14@nate.com 
Re-reading and Rewriting of African American's History and Life in the Viewpoint of Toni Morrison: Through the Analysis of Beloved

of African Americans in American history. Morrison embraces the story of African American's real life in her novels, and strongly emphasizes necessity to re-read and re-write African American history. She claims to dig up forgotten and buried truth on purpose in American history. This paper will focus on that point to proceed this study agreeing on the view of Carafiol Peter.

Morrison tries to use diverse techniques and surrealistic factors to search and discover the truth of American history. It works for black people to recall fragmented memories in history, and re-memory forgotten things and share them with others[2]. Not only white people but also even black people in American society do not want to face up to the truth on the back of history. Believing that author's mission is to reread distorted history of black people and rewrite forgotten past, Morrison has never been negligent in her principles of life.

Novels, especially for modern African American writers, have been important means to recur inequality, racial discrimination and social injustice[3]. Most of African American novels have the characteristic of using the rhetoric, not the existence of a voice but the absence of a voice, or using the oxymoron[4]. Blackness includes the meaning of racial identity and absence. Writing a novel for African American women was survival strategy in reality and the strongest rebellious device against dominant force. Writing is possibility of change, connecting space to convert stereotyped thought, pioneering force to cause change of social and cultural structure[5]. With this power of writing, Morrison insists that American society recall the past and share it in public for the foundational change of social and cultural schemes.

This study will look into the necessity of re-reading and re-writing of American society from the viewpoint of Toni Morrison. It will analyze the main characters' mental loss and restoration in her novel, Beloved for concrete research. Methodologically, this study will examine function of speaking and hearing, recalling and sharing, and healing and restoration for African Americans as the basis of Carafiol peter's assertion. As Toni Morrison emphasizes, African Americans' true reconciliation with themselves will be accomplished through gradual change, and this paper claims that these changes let American society unveil the past and co-exist fairly.

\section{Re-reading and Re-writing of Past}

In this chapter, this study will methodologically suggest 'speaking and hearing', 'recalling and sharing' functions to help African Americans put down their mental luggage and open their heart. To speak and hear each other, and to recall fragmented past memories and collect and 
share them with other people is very important to heal African American's intrinsic scar. Furthermore, to share them with modern people in American society is significant, though black people evidently do not want to remember the painful truth. White people also want to avoid the past atrocity and be free from the historical guiltiness[6]. Therefore black people and white people can't communicate truly, and there is a clear obstacle to reach the truth. They don't open their heart to each other. They seem to communicate and coexist, but it is only superficial. This is not a real reconciliation and real co-existence. This is a serious issue Americans have to solve out, and Morrison constantly sticks to that issue[7].

Morrison has always tried to capture distorted traces of American history and politics in her novels. To give a fragmentary example of it, Morrison points out that American society has highlighted negative aspects of black motherhood. For this work, Morrison also argues that American society should recall the past and share it with others. It is the way for African Americans to heal the scar in their mind.

The main characters in Toni Morrison's novel, Beloved are fragmented mentally and physically[8]. African American women's life was cut off from many things, because African American's mother-centered culture put too much pressure on them. That convention gave extreme burden to African American women physically, mentally and economically. Black women had to take care of their family and they also were responsible for the economy. They could not save time to think of themselves and respect themselves. African American women did not have any mental space to keep their own relationship with others. They were gradually isolating themselves from the community, too. The basic reason for African American women of being cut off from a lot of things around them was their miserable life of slavery. For African Americans, the wounds of life under slavery are shackles that are never blurred or erased. The moment they remember those days, the time of all suffering reappears. This cruel past time was gradually forgotten and forgotten as fragmented and unrecorded.

Bringing up accumulated painful memories from the pent-up space of the past is a painful wound for black Americans and it is feared to jeopardize their current life again. As it is, the most important thing in current life for Seth is to protect her daughter, Denver. Seth only thinks about protecting Denver from the past, and a ghost of the past possesses her present and future. The visit of Pauldi lets Seth and Denver start their journey toward the past memory. Seth's inner world becomes to face up to complicating and chaotic past. It is challenge against violence inflicted to her up to that point, and facing the memory of painful truth killing of her child. It also lets readers observe African American women's life in slavery.

That black man emerged through slavery is, in short, a castrated human figure that has 
Re-reading and Rewriting of African American's History and Life in the Viewpoint of Toni Morrison: Through the Analysis of Beloved

fallen into an animal phase, losing its dignity. This human image is concentrated through Pauldi's memory. 'Walking wanderer', Pauldi has been roving since fleeing the camp, Alfred. He walked toward person, not place. Like a pilgrimage to a loving woman in his heart, he has walked seven years in her direction. With the character of Pauldi, Morrison lets Seth representing wounded African American women rehabilitate new identity through real human relationship. After years with Pauldi, Seth who held back her emotions not to remember her past feels a little stable and hopeful, but it is not real stability. Because Seth knew almost all of black men, Seth witnessed under slavery, were helpless, and they could not be a bastion for black women to keep their human dignity. Now black men are all dead and the last remaining man, Pauldi lets Seth talk about the past and face her present life.

In Beloved, when Pauldi, representing a male figure of black community, came back from his pilgrimage, he tries hard to share and heal Seth's pain by letting her recalling. The clear symbol of Seth's scar, made by whipping of slave owner, represents unhealed her mind. Seth's inner world is so paralyzed that no one can touch it. West Cornel says Seth's identity can be established only when she properly reads meaning of the scar on her back and she can be out of the oppressing past of killing her child.[9] The meaning of wound is the symbol of white ownership in the viewpoint of white slave owners. Amy, a white fugitive woman who helped Seth escape and helped Denver give birth, sees the scar as an image of cherry trees in full bloom. But Seth's mother-in-law, Baby Sucks, sees it as a bloody rose. Black man, Pauldi, sees it the pieces carved by a passionate blacksmith. However, for Seth, it only represents her state of mind. Michael. G. Cooke says, Seth herself should work on restoring voice of herself which was excluded and denied from the discourse of dominance[10].

Parents and children's relationship is the most sublime thing in the world. Parents want to give the best things in the world to their children. However, reckless love can destroy them[11]. Their excessive love can be changed into possessing the other. Seth's practical mind, who tore down the border of herself and her children under the name of mother, is very harsh. Seth can't take a step to move forward, because she is still stuck in a rut of pressure of the past. In the end, Seth's mental pressure and chaotic mind cause the appearance of the ghost, Beloved.

Through these developments, Morrison targets to let the world re-read fragmented memories of American history and re-write their history as it is. Morrison tries to reassemble floating rumors, fragmented memories left in history through speaking and hearing one another. 


\section{Recalling and Sharing of Past}

Distinguishable point of African American literature is that it delineates black people's real life and their death as it is. It tells black people's harsh and long life journey struggling for total freedom and liberation as a human being. It conveys African American's first-hand experience in black's voice, not white's voice[12]. Spitting out their painful history and hearing and sharing it each other is best healing for African Americans, and Morrison tries to let them realize it. She embraces this philosophy in her novel, and Beloved also includes her viewpoint on it.

Morrison uses diverse literary techniques in this novel. She says that nobody can define multi-character nature of Beloved in Beloved Morrison's intention creating Beloved as a multi-character, was to let her express past and present, fact and non-fact, and history and memory doubly and dimensionally. Devorah Horvitz insists that the reason Morrison suggests Beloved's identity ambiguous is to let her cross beyond this world and another world, and to help readers to understand African American's unspeakable experience[13]. Beloved, supernatural, irrational, and mysterious existence enters $124^{\text {th }}$ symbolizing black community and opens the door of their trapped mind in the past. Like Henry Louise mentions, Beloved leads people in $124^{\text {th }}$ to another world of greater experience[14].

Beloved is positive and at the same time negative, attractive and also disgusting, non-visual person who can change her shape with a blank look. By using Beloved having complex aspects, Morrison makes African Americans bring out their traumatic experience. It becomes the first step toward change. The process of change and growing up is seen through the gradual movement of Seth and Pauldi who escape from the trap of the past. The existence of Beloved is ghost of Seth's dead daughter, and simultaneously the symbol of all black people who died in slavery. Beloved has complex identity that cannot be explained as a personal experience. Justine Baillie explains about the complex aspect of Beloved as follows.

There is much more to Beloved than one person can show, and she can also be meant to many people in a different way. She is a catalyst to show her inner world, and also lets other people to reveal themselves. Readers become to recognize how Seth killed her little daughter through Beloved. It shows how Seth forgives herself and reconciles with herself. It shows through Beloved how Seth finally have the peace and freedom[15]. 
Re-reading and Rewriting of African American's History and Life in the Viewpoint of Toni Morrison: Through the Analysis of Beloved

For Seth, realm of human mind is the storing place recalling numberless scars and memories. To stand as a complete human being, African Americans have to bring out countless scars from past memory and cast a light of enlightenment there. In other words, black people can't establish themselves as a whole self until they meet their wounds and harmonize with themselves. By recalling and sharing, and reconciling wounds of the past hidden at the bottom of their consciousness with shame that had weighed them down, African Americans can stand as a free and intact entity.

Morrison emphasizes the power of recalling and sharing, and it is directly related with healing and restoration for African American people. Peter Carafiol explains the importance of memory and speech for black people as follows.

No one speaks out about themselves when they are not forced to spit it out. Nobody wants to do that. Because human being is a fragile existence. Nobody wants to say it. However, once they start talking, they hear and share someone's story, and they realize the fact that it was not just one person's pain, it was two people, three people, and four people's pain. If such people share their pain and experience together, they can heal the individual as well as the group[7].

Speaking needs both speaker and hearer, and it has a basis on the relationship between their own and their companion. The collective nature of speaking, which seeks to understand the community grounded on interrelationship between speaker and listener, enables individual healing[16]. For African Americans, to recall the past and to speak with others about it becomes survival strategy. Likewise, black people can heal their traumatic scar through the function of recalling and sharing the past.

\section{Restoration of Past through Relations}

Beloved plays a role of catalyst to let her mother, Seth restore her identity, and accept herself as she was. Beloved stimulates Seth to recall past painful memory and face it. It lets Seth realize the basic cause of her distorted pathological motherhood which was originated from experience with her mother. She is obsessed with guiltiness of killing her child. She also has the sense of loss with her mother's relationship. Seth, raised by a nanny who lost one arm on behalf of her mother who left work two weeks after birth, had to grow up with alienation and anxiety caused by severing of relations. 
Beloved's simple question if Seth's mother patted her hair makes Seth recall the memory of her mother. Human self is formed in relationship with others, and the first relationship is with their mother. It is gradually extended to family and everyone who forms an individual environment in community. The hardest part of Seth's life in the past was the fact that she murdered her daughter. The relationship with her mother caused it, and it is connected with her sense of loss which conquered her whole life. Eugene argues when parents do not take care of their children themselves, it leads the child to have a mental instability[17]. This unstability separates mother and child, and it becomes an obstacle to child's self-development. The sense of Seth's mental loss is directly related with not only a physical hunger but also a mental hunger, which comes up with Seth's sticking to mother's milk. It symbolizes her mental thirst for motherhood.

Seth was possessed with the obsession of giving mother's milk to her daughter, because it was the way she could express her motherhood. Therefore Seth was excessively attached to keeping breast milk from others.

There was no milk to say it was mine. I did not know what it meant to try and cry for milk. I know what it is like to have only a little left[18].

In slavery, the existence of black father is fundamentally negated, and 'a mother's milk' symbolized by motherhood was the last bastion of human existence. For Seth, motherhood was the only way she could exist as a mother, and its symbol was mother's milk. Seth, who gave birth to a child while defecting from the river, felt restful when she could lean back and hold the baby in her hands and let her baby mouth open and suck the milk. This is the most dramatic moment in this novel, where mother and child could accomplish their emotional communication. Seth's breast-feeding is a sign of strengthening the relationship between her and her daughter.

The $124^{\text {th }}$ Street, symbol of the ordinary black community, becomes a place of chaos and an eery place where Seth and Beloved encounter[19]. The hope of saving their relationships comes from Denver, Seth's second daughter born by combining the courage of a black woman and the compassion of a white woman in the Ohio River, in the border between the South and the North. Restoration of human relations is one of the main themes of Morrison's works, which is significant factor in this novel too. It lets the rebellious daughters come to understand their mother, and it eventually becomes a driving force for her daughters to have strong will to overcome their own lives. 
Re-reading and Rewriting of African American's History and Life in the Viewpoint of Toni Morrison: Through the Analysis of Beloved

Sharing one's own with others through the process of speaking restores one's ego and enables the movement from an object to a subject of oppression and exploitation to a subject[20].

Denver, playing a role of connecter between an isolated black woman, Seth and the black community, conveys Seth's story to them and asks for help. The community responds to it. Seth's story is their story, and the women of the community gather together and pray with objects regarded as Christian symbols that are said to be effective in the folk belief and drive the ghost of Beloved out of their collective memory. Seth, who was away from the trap of the past wounds, now reconciles with the community and herself, and Beloved disappears with a smile. This is Beloved's confirmation for her mother and it at the same time means the reconciliation with the past. There is a natural recovery between Seth and the community. Having become aware of herself as a mother and independent subject, Seth can exist now as a whole being with a free ego.

\section{Conclusion}

The character of Beloved in this novel practically plays a role of friend for Denver, and at the same time destroyer and healer. She also plays a role of catalyst to change the people of community of $124^{\text {th }}$ street. For Pauldi, Beloved lets his red heart which got rusty beat actively again. The past obsession has conquered Seith's consciousness, and she is living at present but mentally living in the past. She was giving up her life of her own and was only hanging on the past that she killed her child. The more Seth tries to be out of the past memory, the more she intimidates her present life. Therefore her life is all messed with the traces of the past.

When Dever asked Seth what she prayed for, Seth explained the memory of time and place, "when fire destroys the house, the house is gone, but the memory - the traces of the memory - never parishes. It stays in their memory... It stays there in the world"[21]. For Seth, the realm of human mind is the storing place recalling the numberless scars and memories. To stand as a complete human being, African Americans have to bring out the scars and memories that cannot be counted even by origin and cast a light of enlightenment there. Until they face up to the scars in their deep heart and harmonize with themselves, African Americans can't be a complete human being. By speaking and hearing each other, recalling and sharing the past one another, they can sincerely heal themselves[22]. They are finally out of the pressure which weighed them down heavily. 
On the basis of Toni Morrison's assertion and Carafiol Peter's criticism, this study examined the direction of American society they have to move on. African American's painful past has to be remembered, but they must not be trapped there forever. Today what African Americans have to keep in mind is to preserve their own healed self and their identity, not the pathetic mind sticking to the past. True sharing and healing through speaking, hearing and recalling the past will be the best way American society can restore black and white's relationship and co-exist equally and vividly.

\section{References}

[1] Paula Giddings, The Triumphant Song of Toni Morrison, Toni Morrison: Conversations, USA: University Press of Mississippi, (2008)

[2] Lock, Alain, Negro Art: Past and Present, USA New York: Grosset and Dunlap, (2000)

[3] Baker Jr, Houston A., Blues, Ideology and Afro-American Literature: A Venacular Theory, USA Chicago: The University of Chicago Press, (2013)

[4] Burrows, Victoria, Whiteness and Trauma, USA: Palgrave Macmillan, (2004)

[5] Li, Stephanie, Toni Morrison: A Biography, USA: Greenwood Press, (2010)

[6] H. Langston, M. Meltzer, Black Magic: A Pictorial History of Negro in American Entertainment, USA New Jersey: Prentice Hall, (2005)

[7] H. Wonham, Criticism and the Color Line: Desegregating American Literacy Studies, USA: Rutgers University Press, (1996)

[8] Manuela López Ramírez, What You Do to Children Matters: Toxic Motherhood in Toni Morrison's Works, ATLANTIS, (2016), Vol.38, No.1, pp.105-122, DOI:10.17561/GROVE.V0I22.2700

[9] Cornel West, Race Matter, USA, Beacon Press, (2001)

[10] Cooke, Michael G., Modern Black Novelists: A Collection of Critical Essays, 1st edition, USA: Prentice Hall, (1971)

[11] Toni Morrison, Toni Morrison: Conversations, USA: University Press of Mississippi, (2008)

[12] Yungkenn Park, Social Story Intervention for Improving the Social Skills for Students with Intellectual Disabilities and Autism Disorder: A Meta-Analysis, International Journal of Child Welfare Promotion and Management, (2018), Vol.2, No.2, pp.81-88, http://dx.doi.org/10.21742/IJCWPM.

[13] Deborah Horvitz, Nameless Ghost: Possession and Dispossession in Beloved, Studies in American Fiction, (1989), Vol.17, No.2, pp.157-167, DOI: 10.1353/saf.1989.0019

[14] Henry Louis Gates Jr, Valerie Smith, William L. Andrews, Kimberly Benston, Brent Hayes Edwards, 
Re-reading and Rewriting of African American's History and Life in the Viewpoint of Toni Morrison: Through the Analysis of Beloved

Frances Smith Foster, Deborah E. McDowell, Robert G. O'Meally, Hortense Spillers, Cheryl A. Wall, The Norton Anthology of African American Literature, (Third edition), W. W. Norton \& Company, (2014)

[15] Baillie, Justine, Toni Morrison and Literary Tradition: The Invention of an Aesthetic, UK London: Bloomsbury Publishing, (2013)

[16] Morrison, Toni, The Site of Memory, USA New York: Houghton Mifflin, (1995)

[17] Eugene Redmond, Interview with Toni Morrison, Toni Morrison's Conversations, USA: University Press of Mississippi, (2008)

[18] Morrison, Toni, Beloved, USA New York: The Knopf Doubleday Publishing Group, (2004)

[19] Henderson, Mae G, Speaking in Tongue and Dancing Diaspora, UK: Oxford University Press, (2014)

[20] Hye-Gyung An, Chae-Min Yoon, The Influential Factors on the Fever Management of Mothers with their First Child in Infancy, International Journal of Child Welfare Promotion and Management, (2019), Vol.3, No.1, pp.1-6, http://dx.doi.org/10.21742/IJCWPM.

[21] Shirley A Stave, Toni Morrison and the Bible : contested intertextualities, New York : Peter Lang, (2006)

[22] Fink Bruce, A Clinical Introduction to Lacanian Psychoanalysis: Theory and Technique, USA; Harvard University Press, (1999) 